\title{
UMA NOVA CANOA
}

A partir dessa edição, a Canoa do Tempo, revista do Programa de Pós-Graduação em História (PPGH/UFAM), inicia uma nova viagem. Pelos rios e igapós amazônicos, a revista passará a ser publicada apenas na versão digital. Com isso, imaginamos poder alcançar um público maior e atingir um patamar ainda mais elevado no que concerne à divulgação das pesquisas, em especial daquelas realizadas no âmbito da Amazônia. Ademais, esperamos superar os problemas de periodicidade que vínhamos enfrentando.

Tendo sido lançada no ano de 2007, a revista desempenhou - e continua a desempenhar - um importante papel no sentido de publicizar as pesquisas que vêm sendo realizadas não apenas sobre a Amazônia, tendo contado com a participação de diversos pesquisadores renomados nesses dez anos de atividades. A fim de recuperar essa bonita trajetória, optamos por disponibilizar os números anteriores - que só estavam disponíveis na versão física - aos usuários do site e leitores em geral.

Aproveitamos a oportunidade para convidar o público a participar dessa viagem conosco, cadastrando-se no site como usuários, autores ou avaliadores. Desejamos uma excelente viagem pelos rios e igapós da História da Amazônia.

César Augusto Bubolz Queirós. 